\title{
Trans-Esterification of Poultry Skin Fat to Produce Biodiesel
}

\author{
Hafiz Anees Rehman, Syed Farman Ali Shah", Aziza Aftab and Zeenat M. Ali \\ ${ }^{I}$ Department of Chemical Engineering, Mehran University of Engineering and Technology, Jamshoro, Sindh, Pakistan. \\ *Corresponding Author Email: farman.shah@ faculty.muet.edu.pk \\ Received 20 September 2016, Revised 24 November 2016, Accepted 30 November 2016
}

\begin{abstract}
Chicken skin and its fat are sources of solid waste that are usually not utilized and add solid pollution. This research work deals with the production of useful biodiesel from utilizing the waste chicken (fat and its skins). Waste chicken fat and its skins (sourced from local shops of Hyderabad, Sindh, Pakistan) were extracted and trans-estrification was made. The product of trans-estrification was fatty acid methyl esters (FAME) commonly known as biodiesel. Sodium Hydroxide ( $\mathrm{NaOH})$ was used as catalyst and glycerol was obtained as a by-product. The FAME produced was tested for six parameters namely calorific value, cloud point, pour point, flash point, density and viscosity when compared to ASTM E2515-11 standard values. The results of this experiment showed that the calorific value, cloud point, pour point, flash point, density and viscosity values of FAME produced from chicken skin and its fat were close to that of petroleum derived diesel.
\end{abstract}

Keywords: Chicken-Skin, Biodiesel, Poultry waste, Esterification, FAME.

\section{Introduction}

In Pakistan 7.2 million tons of furnace oil is consumed per year, whereas the import of diesel and furnace oil is about 9 million tons [1].The Greenhouse gas (GHG) emissions are comparably low in Pakistan contributing $0.43 \%$ of the world's total emissions and ranked at $35^{\text {th }}$ in $\mathrm{GHG}$ emitting countries list. Alternative energy sources are good options for reducing emissions (Carbon, NOx, SOx), cleaning the air, and more sustainable footing of our civilization. Today, world's attention is focused on a promising alternative fuel.

The biodiesel is best alternate source which produces less hydro carbons, $\mathrm{CO}$, and particulate emissions than regular petroleum diesel [2]. The biodiesel can be produced from straight vegetable oil, animal oil/fats, tallow and waste cooking oil by tranestrification $[3,4]$ and can have the potential to meet the global energy needs growing in sense of overall cost-effectiveness and acceptable fuel properties. Improper disposing creates potentially hazardous solid waste and a serious environmental issue. The poultry skin is an economical source of biodiesel production which not only provides the safe disposal but also makes the environment friendly [5].

The biodiesel production comes from skins, fats of chicken or animals and oil seed plants also the material which contains the triglycerides. Chicken skin is preferable to the edible/non edible oils and waste oils as it contains low or negligible impurities [6]. In 2010 (Fig1 \& 2) the larger energy share of world energy consumption is fulfilled by fossil fuels [7, 8]. 


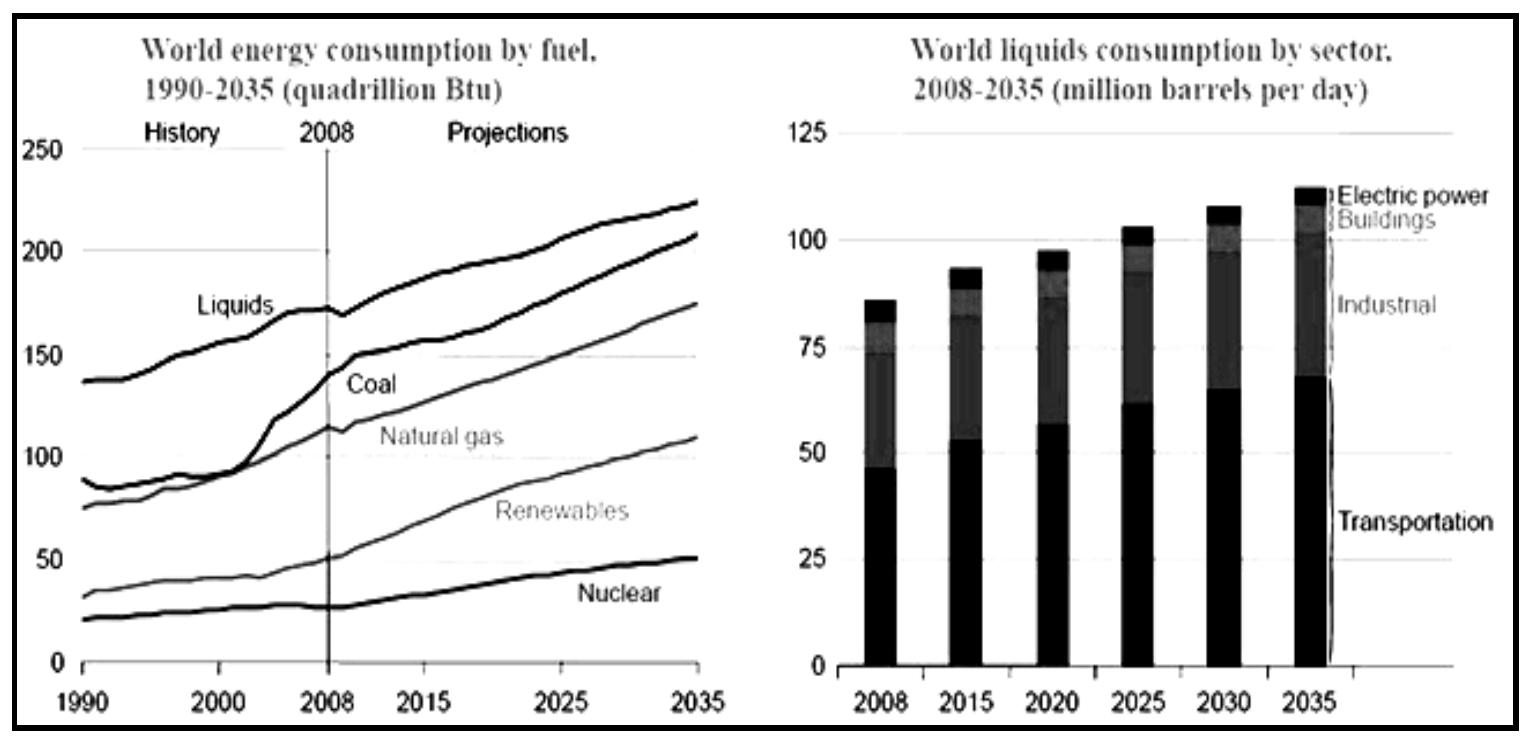

Figure 1. World energy consumption by fuel, 1990-2035 (Quadrillion Btu)

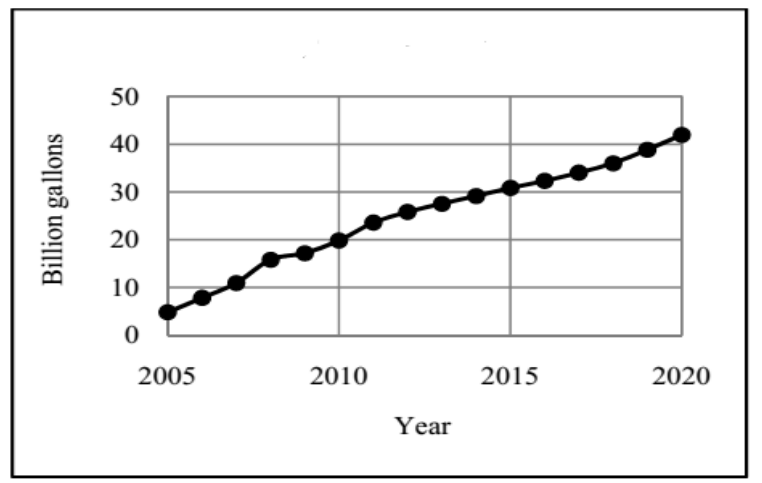

Figure 2. Estimated production of biodiesel up to 2020

The biofuels are commonly known as alkyl esters or fatty acid esters. The biofuels can be produced by trasnesterification from oil with base catalyst or acid catalyst. Another method is formation of alkyl esters prior to that the oils will convert into fatty acid using acid catalyst. The bio fuel production with base catalyst is most common, economical and feasible. Because it proceed at comparatively low temperature $\left(150{ }^{\circ} \mathrm{F}\right)$ and low pressure(20psi) and give high yield around(98\%) with low reaction time[11]. Another method is alcohydrolysis referred to multi step transestrifiaction reaction carried out in presence of catalyst. The $\mathrm{NaOH}, \mathrm{KOH}$ or Meth-oxides are the most common catalysts which convert the triglycerides into di-glycerides, monoglycerides and glycerol. The Meth-oxides such as sodium meth oxides gave better yield than $\mathrm{NaOH}$ and $\mathrm{KOH}$ [12-13].

This study focus the feasibility of biodiesel production from chicken waste in order to meet the energy challenges of the country. The characteristic of prepared biodiesel were also studied.

\section{Materials and Method}

The $1 \mathrm{~kg}$ waste chicken (fats and skins) samples were collected from local chicken stalls of Hyderabad city. It was full of flesh, fat and blood. At first stage was de-feathered and water washed thrice in order to remove all unwanted matters. Then were size into $1-3 \mathrm{~cm}$ through knives. Accurately weighted $900 \mathrm{~g}$ were dip into 1 Liter distilled water and cooked for 9.5 hours and filtered. The filtrate was collected and treated with $250 \mathrm{ml} \mathrm{NaOH}$ solution (4\%) [14-15].The mixture was well shake with alkalis and allowed for settling in separately funnel. It takes around 8 hours when two distinct layers were appeared. Before settling the $10 \mathrm{ml}$ chloroform were also added. The yellowish top layer contained biodiesel [16] which were recovered and analyzed. 


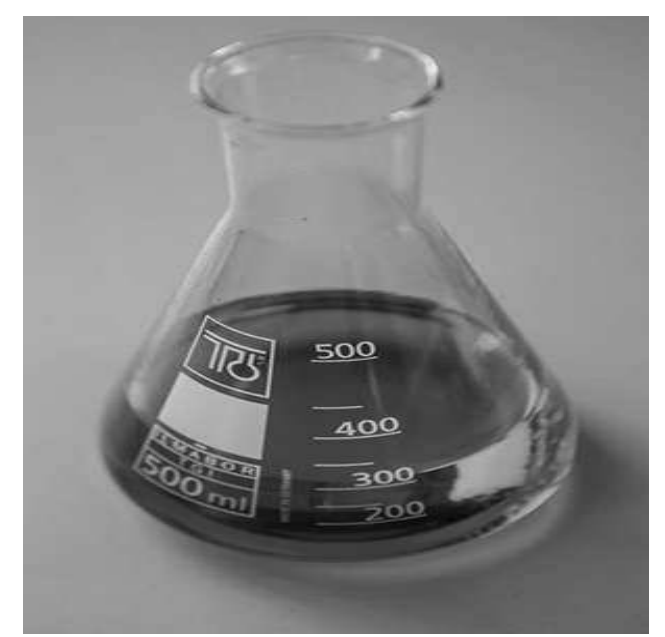

Figure 3. Layer of biodiesel produced from chicken-skin

\section{Results and Discussion}

The experimental study showed that around $57.66 \%$ biodiesel was obtained and was evaluated by given formula.

Biodiesel Obtained $(\%)=\frac{\text { Volume of Biodiesel }}{\text { Amounl ofRawmaterial taken }} \times 100$

The chicken wastes generate per day from Hyderabad shown in table 1 . The study reveals that maximum chicken waste was generated from Latifabad Hyderabad this is because of easily accessible [17] to nearby 6 districts. According to theoretical study the Total amount of chicken sell in Hyderabad daily is approximately $40000 \mathrm{~kg}$. Among which the 4000 of biodiesel \& 577 of glycerol can be obtained by above mentioned formula.

Table 1. Results of Survey of Chicken stall in Hyderabad.

\begin{tabular}{l|lc}
\hline \multicolumn{1}{c|}{$\begin{array}{c}\text { Area in } \\
\text { Hyderabad }\end{array}$} & \multicolumn{1}{c}{ Chicken Stall } & Amount (kg) \\
\hline $\begin{array}{l}\text { Tower } \\
\text { Market }\end{array}$ & $\begin{array}{l}\text { Tawakal Chicken } \\
\text { House \& others } \\
\text { Qasimabad } \\
\text { Qasimabad Chicken } \\
\text { House } \\
\text { Pakistan Chicken } \\
\text { House }\end{array}$ & $2000-3000$ \\
\hline
\end{tabular}

\section{Biodiesel characterization}

From Table 2 it has observed that all the values of parameters of biodiesel are compatible with the properties of Petro-diesel as prescribed through American Society of Testing Materials (ASTM) standards [18].

Table 2. Results of parameters in comparison to ASTM.

\begin{tabular}{lccc}
\hline Parameters & Biodiesel & $\begin{array}{c}\text { Diesel } \\
\text { (Raheman et } \\
\text { al; 2007) }\end{array}$ & ASTM \\
\hline Calorific Value $\left(\mathrm{MJKg}^{-1}\right)$ & 41.5 & 43.5 & 42 \\
Density $\left(\mathrm{gcc}^{-1}\right)$ & 0.88 & 0.85 & 0.87 \\
Kinematic Viscosity (cst) & 5.89 & 2.6 & 6 \\
Flash Point $\left({ }^{0} \mathrm{C}\right)$ & 138 & 64 & 165 \\
Cloud Point $\left({ }^{0} \mathrm{C}\right)$ & 7 & 12 & 9 \\
Pour Point $\left({ }^{0} \mathrm{C}\right)$ & -9 & -10 & -15 \\
\hline
\end{tabular}

It is observed from Fig. 3 that the density of biodiesel obtained through research is closed to ASTM standardized value and slightly different from diesel value [19].

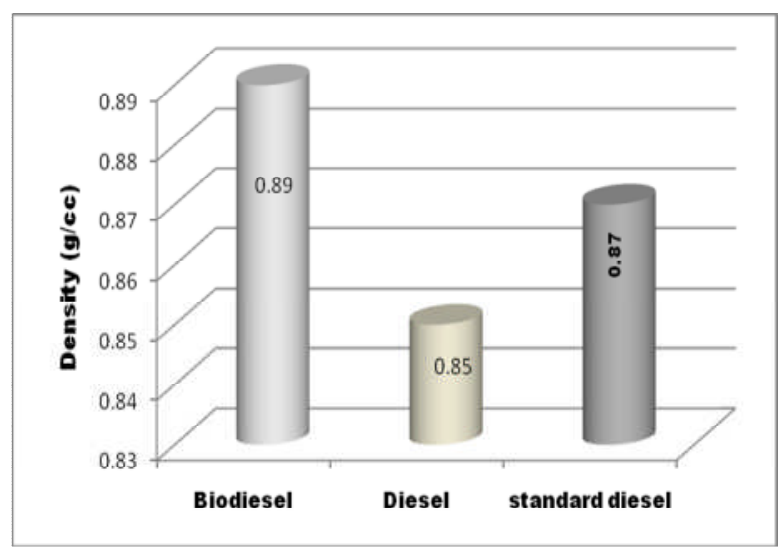

Figure 3. Comparison of the density of Bio-Diesel with diesel

Comparing the net calorific value of bio diesel with diesel from (Fig.4) the calorific value of biodiesel is slightly less than the diesel and very close to ASTM standardized value [20].

Calorific value is the amount of heat given out by the sample per unit mass. It suggests that how much efficient the biodiesel fuel is, whether it is suitable for automobile industry or not. The data of above figure shows that the calorific values of commercial biodiesel sample and biodiesel obtained from chicken skin waste were relatively same $\left(40.2 \mathrm{MJkg}^{-1}\right)$. 


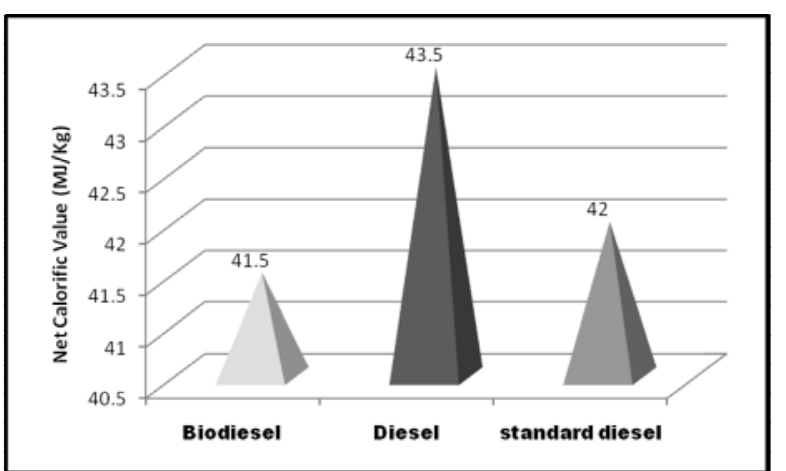

Figure 4. Comparison of the net calorific values of Bio-Diesel with Die

Comparatively high kinematic viscosity was observed in Fig.5 for this product as compared to commercial biodiesel fuel. It shows that there is resistance in the flow of fuel in the internal combustion engine [21].

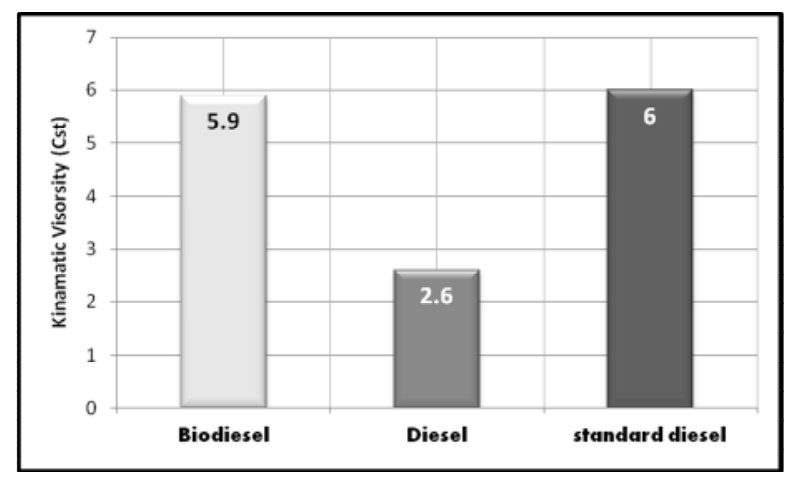

Figure 5. Comparison of the kinematic viscosities of Bio-Diesel with diesel

Fig. 6 shows that the value of pour point of biodiesel is slightly more than ASTM Value but close to the value of diesel.

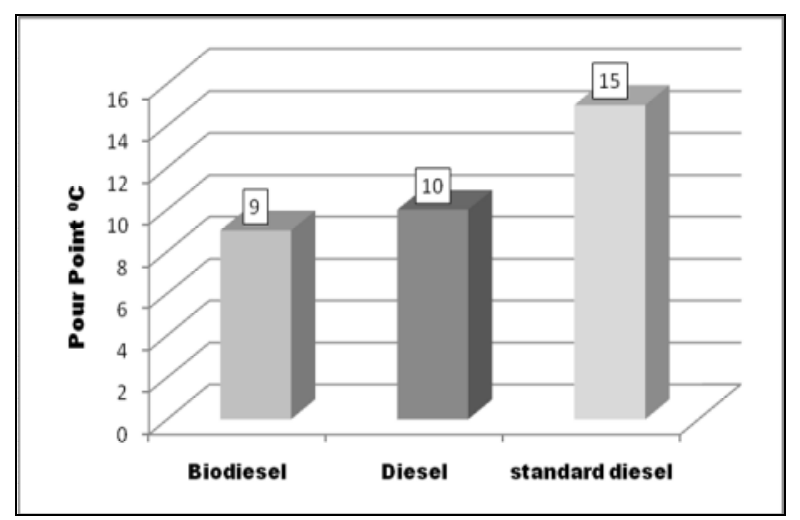

Figure 6. Comparison of the pour points of bio-diesel with diesel
Fig. 7 shows that the flash point of biodiesel is more than the diesel and compatible with ASTM value. Flash point is the temperature at which fuel detonate the energy, the energy is sufficient for the internal combustion.

Fig. 8 shows that the cloud point of biodiesel is slightly less than the value of commercial diesel. However it is compatible with ASTM standard value [22].

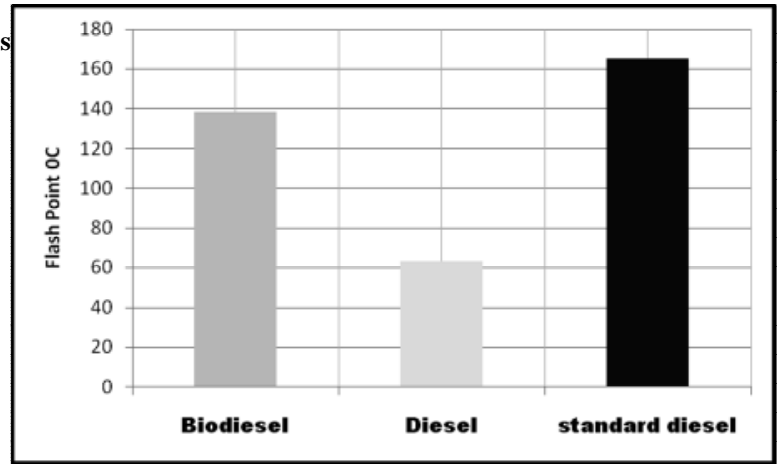

Figure 7. Comparison of the flash points of bio-diesel with diesel

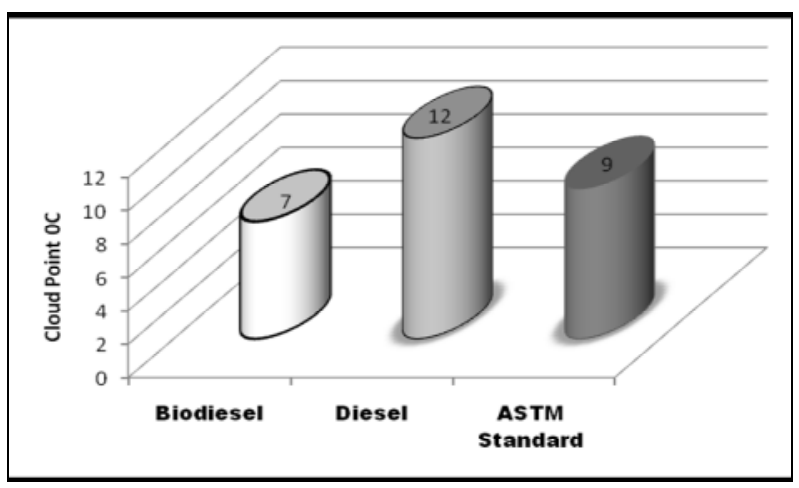

Figure 8. Comparison of the cloud points of bio-diesel with diesel

\section{Conclusion}

It has concluded that fossil fuels reservoirs are depleting day by day. The biodiesel is best substitute of fossil diesel. It can be produced from various sources including the chicken waste. In Hyderabad Sindh the $40000 \mathrm{~kg}$ chicken generated daily. Which can use for biodiesel production be in order to meets energy challenges. The attempted showed that $900 \mathrm{gm}$ chicken waste produced $450 \mathrm{ml}$ biodiesel using $\mathrm{NaOH}$ catalyst. The characteristics of biodiesel were found satisfactory and found 
compatible with the international standards set for biodiesel.

\section{References}

1. A. M. Liaquat, M. A. Kalam, H. H. Masjuki and M. H. Jayed, Atm. Env, 44 (2010) 3869. https://doi.org/10.1016/j.atmosenv.2010.07.0 03

2. M. Canakci, C. Sayin, M. Ilhan and M. Gumus. Ren. Ener., 34 (2009) 1261. https://doi.org/10.1016/j.renene.2008.10.010

3. A. Srivastava and R. Prasad, Ren. and Sust. Ener. Rev., 4 (2000) 111. https://doi.org/10.1016/S13640321(99)00013-1

4. A. K. Azad, M. G. M. M. Rasul, M. M. K. Khan and S. C. Sharma, Ren. and Sus. Ener. Rev., 43 (2015) 331. https://doi.org/10.1016/j.rser.2014.11.047

5. T. KBharat and A. Bhattacharya, Int. J. Eng. Res. and Dev., 2.3 (2012) 8.

6. M. M. K. Bhuiya, M. G. Rasul, M. M. K. Khan, N. Ashwath, A. K. Azad and M. A. Hazrat, Ene. Proc., 61 (2014) 1969. https://doi.org/10.1016/j.egypro.2014.12.054

7. F. M. Farooq and A. Ramli. Ren. Ener. 76 (2015) 362. https://doi.org/10.1016/j.renene.2014.11.042

8. I. C. Andrade, J. P. Santiago, J. R. Sodré, J. S. Pathiyamattom and C. A. G. Fajardo, J. Chem. and Chem. Eng., 8 (2014) 7.

9. C. B Chakra borty, Rajat, Abhishek K. Gupta, and Ratul Chowdhury, Ren. and Sust. Ener. Rev., 29 (2014) 120.

10. G. P. Gustavo Pizarro Lopes, "Biodiesel Production from Poultry Fat” at university de Porto, July (2011).

11. M. M. Tunio, S. R. Samo, Z. M. Ali, A. Q. Jakhrani, K. C. Mukwana, Int. J. Eng. and App. Sc., 3 (2016) 28.
12. V. F. Marulanda, F. Victor, George Anitescu and Lawrence L. Tavlarides, J. Sup. Flu., 1 (2010) 53. https://doi.org/10.1016/j.supflu.2010.04.001

13. A. Cunha, V. Feddern, C. Marina, M. M. Higarashi, P. G. de Abreu and A. Coldebella, Fuel., 105 (2013) 228. https://doi.org/10.1016/j.fuel.2012.06.020

14. B. R. H. Joshi, T. M.Walker, J. Am. Oil Chem. Soc., 89 (2010)145. https://doi.org/10.1007/s11746-011-1891-z

15. B. D. M. Guru, A. A. Keskinand and A. Koca (2009), J. Ener. Con. and Man., 50 (2010) 3 .

16. V. F. Marulanda, G. Anitescu and L. I. Tavlarides, J. Sup. Flu., 54 (2010) 53.

17. M. F. Panhwar, Poultry Farming Practice in Sindh. (2007)

18. I. R. Fattah, H. H. Masjuki, M. A. Kalam, M. A. Hazrat, B. M. Masum, S. Imtenan and A. M. Ashraful, Ren. And Sus. Ener. Rev., 30 (2014) 356. https://doi.org/10.1016/j.rser.2013.10.026

19. U. Rashid and F. Anwar, Fuel, 87 (2008) 265. https://doi.org/10.1016/j.fuel.2007.05.003

20. J. Ahmad, S. Yusup, A. Bokhari and R. N. M. Kamil, Energy Conv. and Manag. 78 (2014) 266. https://doi.org/10.1016/j.enconman.2013.10. 056

21. M. Lapuerta, J. Rodríguez-Fernández, F. Oliva and L. Canoira, Ener. \& Fuel, 23 (2009) 121. https://doi.org/10.1021/ef800481q

22. B. Reyes-Trejo, D. Guerra-Ramírez, H. Zuleta-Prada, Cuevas-Sánchez, J. A., Reyes, L., Reyes-Chumacero, A. and J.A.

Rodríguez-Salazar, Annona, Industrial Crop and Prod. 52 (2014) 400. https://doi.org/10.1016/j.indcrop.2013.11.00 5 